\title{
Heavy Metals Distribution in Soil at Different Depths and Radiuses around Landfills in Districts of Nyékonakpoè, Akodesséwa and Amoutivé in Lomé City
}

\author{
Goliyendou Yandi, Gbénonchi Mawussi*, Amen Yawo Nenonene, Komla Sanda \\ Laboratory of Research on Agroresources and Environmental Health \\ Ecole Supérieure d'Agronomie, Université de Lomé, B. P. 1515, Lomé, Togo. \\ ${ }^{*}$ Corresponding author's email: gmawussi [AT] gmail.com \\ Authors' emails: goliyendou@gmail.com \\ gmawussi@gmail.com \\ amen.nenonene@gmail.com \\ komla.sanda@gmail.com \\ *Corresponding author's email: gmawussi [AT] gmail.com
}

\begin{abstract}
This study aims to provide baseline data about soil contamination by some heavy metals at different depths around landfills in areas at high risk of groundwater contamination. Soil samples were taken in three replicates at depth of 0 $20 \mathrm{~cm}, 20-40 \mathrm{~cm}$ and $40-60 \mathrm{~cm}$ in the radiuses of 0 to $10 \mathrm{~m}, 10$ to $20 \mathrm{~m}$ and 20 to $30 \mathrm{~m}$ around landfills. In all, 81 homogenized composite soil samples were collected. The heavy metals were measured in soil samples by atomic absorption spectrophotometer. The results show that the concentration of mercury $\left(0.03-0.29 \mathrm{mg} \mathrm{kg}^{-1}\right)$, cadmium $(0.04$ $\left.-0.69 \mathrm{mg} \mathrm{kg}^{-1}\right)$, arsenic $\left(0.05-2.30 \mathrm{mg} \mathrm{kg}^{-1}\right)$ and nickel $\left(0.05-2.35 \mathrm{mg} \mathrm{kg}{ }^{-1}\right)$ in analyzed soil samples were lower than the limit values set by WHO, Finland and Dutch environment ministries. However, lead concentrations $(90.15$ - 129.14 mg $\left.\mathrm{kg}^{-1}\right)$ in topsoil in vicinity of landfills in Amoutivé and Akodesséwa were above reference values set by WHO, Finland and Dutch environment ministries. As the heavy metals may be leached to reach groundwater, the landfills management must be great concern to municipal authorities. The frequent monitoring of the quality of soil and groundwater will be necessary to follow the level environmental contamination by heavy metals around landfills and the possible initiate remedial measures.
\end{abstract}

Keywords: Landfill, heavy metal, soil contamination. 


\section{INTRODUCTION}

Landfilling still remains the most common form of removal and disposal of household solid waste in Lomé city as in others cities in West African countries. The solid waste landfills contain hazardous materials which are potential sources of soil, groundwater and plant contamination by heavy metals [1]. Leaching of heavy metals is the process through which contaminants are released into the environment upon contact with water [2]. Landfill leachate produced from a combination of decomposing waste and liquids percolating through waste in landfills is the main vector of these contaminants from the landfill to the environment [3]. Heavy metals constitute real problems in waste management because of their multiple sources and their potentially high toxicity [4]. They have been reported to produce damaging effects on human and animals because there is no good mechanism for their elimination from the body [5].

Togo, like many developing countries, knows the real waste environmental problems. The literature reported that lagoon systems in urbanized areas are easily exposed to inorganic, in particular heavy metals [6]. Unfortunately, the solid waste landfills in the districts of Nyékonakpoè, Akodesséwa and Amoutivé situated between Lomé city lagoon system and Atlantic Ocean are located on the coastal sandy soil with high permeability and high risk of groundwater contamination. Although some studies have been carried out in Togo on some heavy metals in urban waste composting [4] and their accumulation in aquatic ecosystems [7, 8, 9], few attentions has been paid about soil contamination around dumping. The lateral and vertical distributions of heavy metals into soil can pose potential health risks to inhabitants around landfills if these metals migrate into groundwater. Soils contaminated by heavy metals have received special attention because of their serious threats to the food chain, human health and terrestrial ecosystems [10]. It is therefore important to understand the concentration heavy metal level in soil surrounding the solid waste landfills everywhere.

The objective of this study is to determine the presence and concentration of some heavy metals as mercury, lead, nickel, cadmium and arsenic in soil at different depths and radiuses around solid waste landfills in three districts in Lomé city.

\section{MATERIAL AND METHODS}

\subsection{Study area}

The study was carried out in coastal plain in the districts of Nyékonakpoè, Amoutivé and Akodesséwa situated between Lomé city lagoon system and Atlantic Ocean. The sites selection was based on the types of the landfill, waste collected and localisation. The geographic position of the landfills in space were determined using a geographic positioning system

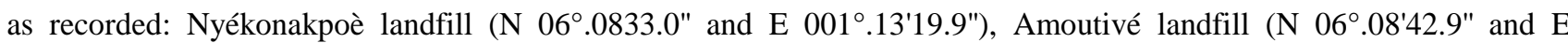
$\left.001^{\circ} .13^{\prime} 54.6^{\prime \prime}\right)$ and Akodesséwa landfill (N 06 .09'17.6" and E 001 $\left.{ }^{\circ} 15^{\prime} 40.8^{\prime \prime}\right)$. The soils of the study area are deeps, nongravelly with sandy texture. These are mineral hydromorphic leached soils with low humus content where the groundwater rises and emerges in the rainy season.

\subsection{Laboratory material}

These are chemical reagents, nitric acid $\left(\mathrm{HNO}_{3}\right)$ and chloruretic acid $(\mathrm{HCl})$ used for the digestion, Sartorius $\mathrm{CP} 225 \mathrm{D}$ analytical microscale (Data Weighting Systems, IL, USA), and Ethos EZ microwave digestor (Milestones, CT, USA), Inductively Coupled Plasma Atomic Emission Spectrometer Optima 3000 XL (Perkin Elmer, CA, USA), calibration standard solution (Fisher Scientific, CA, USA). All chemicals reagents used were analytical grade. Deionized water was used to prepare samples and standards for analysis.

\subsection{Samples collection and preparation}

Soil samples were collected at various points at different depths and radiuses around solid waste landfills. They were taken in the radiuses of 0 to $10 \mathrm{~m}, 10$ to $20 \mathrm{~m}$ and 20 to $30 \mathrm{~m}$ around each landfill. They were collected at three replicates at depths of $0-20 \mathrm{~cm}, 20-40 \mathrm{~cm}$ and $40-60 \mathrm{~cm}$. Usually, five subsamples taken from five different points were merged into one single sample (homogenized composite sample). At each sampling point, a volume of $10 \times 10 \times 10 \mathrm{~cm}$ of soil sample was cut out successively from upper $0-20 \mathrm{~cm}$ layer, (the topsoil) and the bottom $20-40 \mathrm{~cm}$ and $40-60 \mathrm{~cm}$ layer (the subsoil) of soil pits. In all, 81 homogenized composite soil samples were collected from all sites. All soil samples were sealed with polythene bags and transported to laboratory where they were prepared for analysis. 


\subsection{Soil samples analyses}

The soil composite samples were air-dried, homogenized and sieved through a $2 \mathrm{~mm}$ screen. For heavy metals content determination (adapted from Deheyn and Latz [11]), the soil samples were crushed in a silicon mortar and the $<63 \mu \mathrm{m}$ fraction separated by dry sieving. About $0.2 \mathrm{~g}$ of that fraction was weighed using a Sartorius CP225D analytical microscale (Data Weighting Systems, IL, USA) connected to notebook computer for accurate recording of measurements. Samples were then taken in Teflon digestion vessels and partially digested during 20 min in a $\mathrm{HCl}: \mathrm{HNO}_{3}(3: 1)$ mixture at $80^{\circ} \mathrm{C}$ using Ethos EZ microwave digestor (Milestones, $\mathrm{CT}$, USA). Heavy metals (As, $\mathrm{Cd}, \mathrm{Pb}, \mathrm{Ni}$ and $\mathrm{Hg}$ ) were analyzed simultaneously using an Inductively Coupled Plasma Atomic Emission Spectrometer Optima 3000 XL (Perkin Elmer, CA, USA) with detection limits ranging from $0.05^{*} 10^{-6}$ to $4.0^{*} 10^{-6} \mathrm{mg} \mathrm{g}^{-1}$ depending on the element [7]. The instrument, available at the Analytical Facility of the Scripps Institution of Oceanography, was calibrated before every run by successive dilution of $100 \mu \mathrm{g} \mathrm{g}^{-1}$ multi-element instrument calibration standard solution (Fisher Scientific, CA, USA). Recovery of the quality assurance standards was analyzed every 20 samples over the course of the run was $105 \%$, while internal blanks were analyzed to assess any background contamination originating from the sample manipulation was negligible. The regulatory standards for heavy metal levels in soil have been established, but some discrepancy exists among different standards regarding the critical value of each contaminant (Table 1).

Table 1: Threshold and guideline values of heavy metals in soils $\left(\mathrm{mg} \mathrm{kg}^{-1}\right)$

\begin{tabular}{|l|l|l|l|l|l|}
\hline Reference standards & \multicolumn{1}{|c|}{$\mathrm{Cd}$} & \multicolumn{1}{|c|}{$\mathrm{Pb}$} & \multicolumn{1}{|c|}{$\mathrm{Hg}$} & \multicolumn{1}{|c|}{$\mathrm{Ni}$} & \multicolumn{1}{|c|}{ As } \\
\hline Dutch Ministry of Housing, Spatial Planning and the Environment [12] & 0.8 & 85 & 0.3 & 35 & 29 \\
\hline Ministry of the Environment, Finland [13] & 1 & 60 & 0.5 & 50 & 5 \\
\hline WHO [14] & 0.35 & 100 & - & 50 & 40 \\
\hline
\end{tabular}

\subsection{Statistical analysis}

All the data were subjected to statistical analysis. The averages and standards deviations were performed using STATISTICA software (2005, 7.1 Version). The results were expressed as means \pm standard error (SE).

\section{RESULTS AND DISCUSSION}

The study results show the presence of heavy metals $(\mathrm{Cd}, \mathrm{Pb}, \mathrm{Ni}, \mathrm{As}$ and $\mathrm{Hg})$ in soil around the landfills at various concentrations (Tables 2 to 4). This justifies the fact that most landfills in developing countries are illegal dumps without regulatory control [15]. The mean concentrations of heavy metal in soil varied with depths. The concentrations of all heavy metal in topsoil (0-20 cm) were higher than those found in subsoil at 20-40 $\mathrm{cm}$ and 40-60 $\mathrm{cm}$ (Tables 2 to 4 ). These decrease when soil depth increase. It can be assumed that the subsoil is considerably less influenced by contamination processes than the topsoil. In general, it is admitted in literature that the contaminants are found in the topsoil and beyond this layer they can directly reach the groundwater [16]. The heavy metal concentrations varied with distances away from the landfill. This agrees with the results of Olafisoye et al. [17] and Othman et al. [18] who reported that the concentrations of heavy metals decreased as the soil sampling distance from the dump increased. Except for lead $(\mathrm{Pb})$, the concentrations of other heavy metals in soils of the study area were lower when compared to some soil quality guidelines [12, 13, 14] (Tables 1 to 4).

The lead is known as a toxic metal with exceptionally low mobility and persistent in topsoil for a long time [19]. The concentrations of lead $(\mathrm{Pb})$ in soils around landfills recorded in case of this study were higher than those hardly exceeding $2.15 \mathrm{mg} \mathrm{kg}^{-1}$ in soil of Enyimba dumpsite in Aba, Southeastern Nigeria [20]. The concentrations of lead in soil around Nyékonakpoè landfill ranged from 0.51 to $44.58 \mathrm{mg} \mathrm{kg}^{-1}$ and were 3 and 2 times less than that obtained respectively from Akodesséwa landfill $\left(2.01-129.14 \mathrm{mg} \mathrm{kg}^{-1}\right)$ and Amoutivé landfill $\left(1.09-90.15 \mathrm{mg} \mathrm{kg}^{-1}\right)$. The data suggested that the Akodesséwa and Amoutivé landfill sites were more contaminated by $\mathrm{Pb}$ than the Nyékonakpoè landfill site. The concentrations of $\mathrm{Pb}$ in the radius of 0 to $10 \mathrm{~m}$ around landfill were higher than those recorded in the radiuses of 10 to 20 
$\mathrm{m}$ and 20 to $30 \mathrm{~m}$ (Tables 2 to 4). This is in accordance with the conclusions of Olafisoye et al. [17] who reported that the concentrations of heavy metals decreased as the soil sampling point distance from the dump increased.

Table 2: Heavy metal concentrations in soil $\left(\mathrm{mg} \mathrm{kg}^{-1}\right)$ at different depths in a radius of 0 to $10 \mathrm{~m}$ around solid waste landfills in three districts in Lomé city

\begin{tabular}{|c|l|l|l|l|l|l|}
\hline Districts & \multicolumn{1}{|c|}{$\begin{array}{c}\text { Soil layer } \\
(\mathrm{cm})\end{array}$} & \multicolumn{1}{|c|}{$\mathrm{Cd}$} & \multicolumn{1}{|c|}{$\mathrm{Pb}$} & \multicolumn{1}{|c|}{$\mathrm{Hi}$} & \multicolumn{1}{c|}{ As } \\
\hline \multirow{4}{*}{ Nyékonakpoè } & $0-20$ & $0.34 \pm 0.04$ & $44.58 \pm 1.15$ & $0.19 \pm 0.02$ & $1.19 \pm 0.07$ & $1.28 \pm 0.06$ \\
\cline { 2 - 7 } & $20-40$ & $0.11 \pm 0.02$ & $13.37 \pm 0.12$ & $0.03 \pm 0.01$ & $0.35 \pm 0.02$ & $0.51 \pm 0.03$ \\
\cline { 2 - 7 } & $40-60$ & $\mathrm{ND}$ & $4.01 \pm 0.09$ & $\mathrm{ND}$ & $0.11 \pm 0.01$ & $\mathrm{ND}$ \\
\hline \multirow{4}{*}{ Amoutivé } & $0-20$ & $0.48 \pm 0.02$ & $90.15 \pm 1.80$ & $0.23 \pm 0.02$ & $1.81 \pm 0.08$ & $2.26 \pm 0.08$ \\
\cline { 2 - 7 } & $20-40$ & $0.14 \pm 0.01$ & $27.04 \pm 1.10$ & $\mathrm{ND}$ & $0.54 \pm 0.04$ & $0.53 \pm 0.02$ \\
\cline { 2 - 7 } & $40-60$ & $\mathrm{ND}$ & $8.11 \pm 0.15$ & $\mathrm{ND}$ & $0.15 \pm 0.02$ & $\mathrm{ND}$ \\
\hline \multirow{4}{*}{ Akodesséwa } & $0-20$ & $0.69 \pm 0.05$ & $129.14 \pm 2.9$ & $0.29 \pm 0.03$ & $2.35 \pm 0.09$ & $2.30 \pm 0.09$ \\
\cline { 2 - 7 } & $20-40$ & $0.21 \pm 0.02$ & $38.75 \pm 1.12$ & $\mathrm{ND}$ & $0.70 \pm 0.05$ & $0.55 \pm 0.03$ \\
\cline { 2 - 7 } & $40-60$ & $\mathrm{ND}$ & $11.10 \pm 0.11$ & $\mathrm{ND}$ & $0.22 \pm 0.03$ & $\mathrm{ND}$ \\
\hline
\end{tabular}

ND: stands for Not Detectable.

Table 3: Heavy metal concentrations in soil $\left(\mathrm{mg} \mathrm{kg}^{-1}\right)$ at different depths in a radius of 10 to $20 \mathrm{~m}$ around solid waste landfills in three districts in Lomé city

\begin{tabular}{|c|l|l|l|l|l|l|}
\hline \multicolumn{1}{|c|}{ Districts } & \multicolumn{1}{|c|}{$\begin{array}{c}\text { Soil layer } \\
(\mathrm{cm})\end{array}$} & \multicolumn{1}{|c|}{$\mathrm{Cd}$} & \multicolumn{1}{|c|}{$\mathrm{Pb}$} & \multicolumn{1}{|c|}{$\mathrm{Ni}$} & \multicolumn{1}{c|}{ As } \\
\hline \multirow{5}{*}{ Nyékonakpoè } & $0-20$ & $0.04 \pm 0.01$ & $14.06 \pm 1.10$ & $0.05 \pm 0.02$ & $0.53 \pm 0.03$ & $0.31 \pm 0.07$ \\
\cline { 2 - 7 } & $20-40$ & $\mathrm{ND}$ & $3.89 \pm 0.17$ & $\mathrm{ND}$ & $0.16 \pm 0.02$ & $0.06 \pm 0.01$ \\
\cline { 2 - 7 } & $40-60$ & $\mathrm{ND}$ & $1.17 \pm 0.02$ & $\mathrm{ND}$ & $\mathrm{ND}$ & $\mathrm{ND}$ \\
\hline \multirow{4}{*}{ Amoutivé } & $0-20$ & $0.05 \pm 0.02$ & $28.56 \pm 1.15$ & $0.06 \pm 0.01$ & $0.82 \pm 0.04$ & $0.52 \pm 0.02$ \\
\cline { 2 - 7 } & $20-40$ & $\mathrm{ND}$ & $8.33 \pm 0.13$ & $\mathrm{ND}$ & $0.25 \pm 0.01$ & $0.15 \pm 0.01$ \\
\cline { 2 - 7 } & $40-60$ & $\mathrm{ND}$ & $2.49 \pm 0.08$ & $\mathrm{ND}$ & $\mathrm{ND}$ & $\mathrm{ND}$ \\
\hline \multirow{3}{*}{ Akodesséwa } & $0-20$ & $0.09 \pm 0.03$ & $39.09 \pm 1.14$ & $0.06 \pm 0.01$ & $1.05 \pm 0.09$ & $0.55 \pm 0.02$ \\
\cline { 2 - 7 } & $20-40$ & $\mathrm{ND}$ & $11.72 \pm 0.19$ & $\mathrm{ND}$ & $0.31 \pm 0.02$ & $0.16 \pm 0.01$ \\
\cline { 2 - 7 } & $40-60$ & $\mathrm{ND}$ & $3.51 \pm 0.11$ & $\mathrm{ND}$ & $\mathrm{ND}$ & $\mathrm{ND}$ \\
\hline
\end{tabular}

ND: stands for Not Detectable.

For $\mathrm{Ni}$, the mean concentrations in soil around Akodesséwa landfill $\left(0.09-2.35 \mathrm{mg} \mathrm{kg}^{-1}\right)$ and Amoutivé landfill (0.07 $\left.1.81 \mathrm{mg} \mathrm{kg}^{-1}\right)$ were approximately and respectively about 2 and 1.5 times greater than that recorded around Nyékonakpoè landfill $\left(0.05-1.19 \mathrm{mg} \mathrm{kg}^{-1}\right)$. The relative highest presence of $\mathrm{Ni}$ in soil around Akodesséwa landfill could indicate that this landfill received some industrial wastes, especially since Akodesséwa district is an industrial port area. The Ni in soil may be from municipal waste and nickel-cadmium batteries. The mean value concentrations of Ni found in this study were below those of various standards $[12,13,14]$. The variation of $\mathrm{Ni}$ concentration in soil depending to depth and radius around the landfill (Tables 2 to 4) were similar to what has been reported by Makuleke and Ngole-Jeme [3] and Olafisoye et al. [17] who concluded that the heavy metal concentration levels were affected by soil depth and sampling point distance from landfill.

Table 4: Heavy metal concentrations in soil $\left(\mathrm{mg} \mathrm{kg}^{-1}\right)$ at different depths in a radius of 20 to $30 \mathrm{~m}$ around solid waste landfills in three districts in Lomé city

\begin{tabular}{|c|c|c|c|c|c|c|}
\hline Districts & $\begin{array}{c}\text { Soil layer } \\
(\mathrm{cm})\end{array}$ & $\mathrm{Cd}$ & $\mathrm{Pb}$ & $\mathrm{Hg}$ & $\mathrm{Ni}$ & As \\
\hline
\end{tabular}




\begin{tabular}{|l|l|l|l|l|l|l|}
\hline \multirow{4}{*}{ Nyékonakpoè } & $0-20$ & $0.04 \pm 0.01$ & $5.79 \pm 0.18$ & $0.05 \pm 0.02$ & $0.05 \pm 0.01$ & $0.05 \pm 0.02$ \\
\cline { 2 - 7 } & $20-40$ & $\mathrm{ND}$ & $1.73 \pm 0.11$ & $\mathrm{ND}$ & $\mathrm{ND}$ & $\mathrm{ND}$ \\
\cline { 2 - 7 } & $40-60$ & $\mathrm{ND}$ & $0.51 \pm 0.02$ & $\mathrm{ND}$ & $\mathrm{ND}$ & $\mathrm{ND}$ \\
\hline \multirow{4}{*}{ Amoutivé } & $0-20$ & $0.07 \pm 0.01$ & $12.10 \pm 0.13$ & $0.05 \pm 0.02$ & $0.07 \pm 0.03$ & $0.06 \pm 0.02$ \\
\cline { 2 - 7 } & $20-40$ & $\mathrm{ND}$ & $3.63 \pm 0.14$ & $\mathrm{ND}$ & $\mathrm{ND}$ & $\mathrm{ND}$ \\
\cline { 2 - 7 } & $40-60$ & $\mathrm{ND}$ & $1.09 \pm 0.10$ & $\mathrm{ND}$ & $\mathrm{ND}$ & $\mathrm{ND}$ \\
\hline \multirow{3}{*}{ Akodesséwa } & $0-20$ & $0.09 \pm 0.02$ & $20.59 \pm 1.02$ & $0.06 \pm 0.03$ & $0.09 \pm 0.04$ & $0.06 \pm 0.03$ \\
\cline { 2 - 7 } & $20-40$ & $\mathrm{ND}$ & $6.17 \pm 0.15$ & $\mathrm{ND}$ & $\mathrm{ND}$ & $\mathrm{ND}$ \\
\cline { 2 - 7 } & $40-60$ & $\mathrm{ND}$ & $2.01 \pm 0.12$ & $\mathrm{ND}$ & $\mathrm{ND}$ & $\mathrm{ND}$ \\
\hline
\end{tabular}

ND: stands for Not Detectable.

The concentrations of cadmium (Cd) were found low in soil at all sampling points around landfills. The levels of $\mathrm{Cd}$ recorded in this study $\left(0.04-0.69 \mathrm{mg} \mathrm{kg}^{-1}\right)$ were below those $\left(1.86-2.87 \mathrm{mg} \mathrm{kg}^{-1}\right)$ found in soil from dump sites in Kumasi suburbs at Ayigya, Buokrom and Abrepo [21]. It may indicate naturally low concentrations of this heavy metal in the soil. The concentrations of $\mathrm{Cd}$ found in soil around Akodesséwa landfill $\left(0.69 \mathrm{mg} \mathrm{kg}^{-1}\right)$ were higher than the WHO permissible limits $\left(0.35 \mathrm{mg} \mathrm{kg}^{-1}\right)$ but below Dutch standard $\left(0.8 \mathrm{mg} \mathrm{kg}^{-1}\right)$ (Tables 1 to 4$)$. The absence of $\mathrm{Cd}$ in soil horizon $40-60 \mathrm{~cm}$ indicates the low mobility of this heavy metal [22]. The highest average concentration of arsenic $\left(2.30 \mathrm{mg} \mathrm{kg}^{-1}\right)$ was recorded in topsoil at radius of 0 to $10 \mathrm{~m}$ around Akodesséwa landfill. This value was about 2 times, 12 times and 17 times less than Finland, Dutch and WHO standard limits respectively. The mean values of mercury $(\mathrm{Hg})$ ranged from 0.05 to $0.29 \mathrm{mg} \mathrm{kg}^{-1}$ in soil around Akodesséwa landfill, from 0.05 to $0.23 \mathrm{mg} \mathrm{kg}^{-1}$ in soil around Amoutivé landfill and from 0.03 to $0.19 \mathrm{mg} \mathrm{kg}^{-1}$ in soil around Nyékonakpoè landfill. These values were below the various reference limits set by [12, 13,14] (Tables 1 to 4). Based on the limit values of reference, there are no health risks related to the concentrations of arsenic and mercury in soil around the landfills in the study area.

\section{CONCLUSION}

Five heavy metals have been determined in soil at different depths and radiuses around landfills. Their concentrations varied with soil depth and distance away from the landfill. The mechanisms of their distribution and accumulation in soil remain poorly understood. The identification of key factors controlling their distribution and accumulation in soil around landfills will be greater preoccupation in the future researches to understand the mechanism of soil contamination around landfill in response to interactions with environmental factors.

\section{ACKNOWLEDGEMENTS}

Authors thank Laboratory of Management, Treatment and Value of Waste, University of Lomé (GTVD/UL) for its kind support and cooperation in carrying out soil samples analysis.

\section{REFERENCES}

[1] Gworek B., Dmuchowski W., Koda E., Marecka M., Baczewska A.H., Br agoszewska P., Sieczka A. and Osí nski P. Impact of the municipal solid waste Lubna landfill on environmental pollution by heavy metals. Water, vol. 8, $\mathrm{n}^{\circ}$ 470, pp. 1-16, 2016.

[2] Wuana R.A. and Okieimen F.E. Heavy metals in contaminated soils: A review of sources, chemistry, risks and best available strategies for remediation. International Scholarly Research Network, pp. 1-20, 2011.

[3] Makuleke P. and Ngole-Jeme V.M. Soil heavy metal distribution with depth around a closed landfill and their uptake by Datura stramonium. Applied and Environmental Soil Science, pp. 1-14, 2020.

[4] Koledzi E.K., Baba G., Tchegueni S., Segbeaya K.N., Koriko M., Matejka G. and Tchangbedji G. Fate of some heavy metals in the composting of the urban solid waste produced in Lome, Togo. Journal of Environmental Chemistry and Ecotoxicology, vol. 5, n 7, pp. 196-201, 2013. 
[5] Adah C.A., Abah J., Ubwa S.T. and Ekele S. Soil availability and uptake of some heavy metals by three staple vegetables commonly cultivated along the south bank of River Benue, Makurdi, Nigeria. International Journal of Environment and Bioenergy, vol. 8, n², pp. 56-67, 2013.

[6] Tiefenthaler L.L., Stein E.D. and Schiff K.C. Watershed and land use-based sources of trace metals in urban storm water. Environmental Toxicology and Chemistry, vol. 27, pp. 277-287, 2008.

[7] Gnandi K., Han S., Rezaie-Boroon M.H., Porrachia M. and Deheyn D.D. Increased bioavailability of mercury in the lagoons of Lomé Togo: the possible role of dredging. AMBIO Springer, vol. 40, pp. 26-42, 2011.

[8] Ouro-Sama K., Solitoke H.D., Gnandi K., Afiademanyo K.M. and Bowessidjaou E.J. Evaluation et risques sanitaires de la bioaccumulation de métaux lourds chez les espèces halieutiques du système lagunaire togolais. Vertigo, vol. $14, \mathrm{n}^{\circ} 2$, pp. 1-18, 2014.

[9] Kondo K.F., Afiademanyo K.M., Ouro-Sama K., Solitoke H.D. and Gnandi K. Heavy metal contamination levels in clams (Galatea paradoxa, B. 1778) and surface sediments from Mono River Estuary, Togo, and its health implications. Journal of Biology, Agriculture and Healthcare, vol. 11, n 4, pp. 81-94, 2021.

[10] Rajmohan N. Prathapar S.A., Jayaprakash M. and Nagarajan R. Vertical distribution of heavy metals in soil profile in a seasonally water logging agriculture field in Eastern Ganges Basin. Environmental Monitoring and Assessment, vol. $186, n^{\circ} 9$, pp. $5411-5427,2014$

[11] Deheyn D.D. and Latz M.I. Bioavailability of metals along a contamination gradient in San Diego Bay (California, USA). Chemosphere, vol. 63, pp. 818-834, 2006.

[12] Dutch Ministry of Housing, Spatial Planning and the Environment Circular on target and intervention values for soil remediation, Reference DBO/1999226863, 2000.

[13] Ministry of the Environment, Finland, "Government decree on the assessment of soil contamination and remediation needs" 214/2007, March 1, 2007.

[14] WHO (World Health Organization), Library cataloguing in publication data, 2007.

[15] Boateng T.K., Opoku F. and Akoto O. Heavy metal contamination assessment of groundwater quality: a case study of Oti landfill site, Kumasi. Applied Water Science, vol. 9, n³3, pp. 1-15, 2019.

[16] Alam M.S., Han B., and Al-Mizan J.P. Assessment of soil and groundwater contamination at a former Tannery district in Dhaka, Bangladesh. Environmental Geochemistry and Health, vol. 42, pp. 1905-1920, 2020.

[17] Olafisoye O.B., Tejumade A. and Osibote O.A. Heavy metals contamination of water, soil, and plants around an electronic waste dumpsite. Polish Journal of Environmental Studies, vol. 22, n5, PP. 1431-1439, 2013.

[18] Othman R., Mohd Latiff N.H., Baharuddin Z.M., Hashim K.S.H.Y. and Lukman Hakim Mahamod L.H. Closed landfill heavy metal contamination distribution profiles at different soil depths and radiuses. Applied Ecology and Environmental Research, vol. 17, n4, pp. 8059-8067, 2019.

[19] Rweyemamu A.R., Nkansah M.A., Darko G. and Dodd M. Contamination and human health risk due to toxic metals in dust from transport stations in the Kumasi Metropolis, Ghana. Chemistry Africa, vol. 3, pp. 831-843, 2020.

[20] Amadi A.N. and Nwankwoala H.O. Evaluation of heavy metal in soils from Enyimba Dumpsite in Aba, Southeastern Nigeria using contamination factor and geo-accumulation index. Energy and Environment Research, vol. 3, n ${ }^{\circ}$, pp. 125-134, 2013.

[21] Odai S.N., Mensah E., Sipitey D., Ryo S. and Awuah E. Heavy metals uptake by vegetables cultivated on urban waste dumpsites: case Study of Kumasi, Ghana. Research Journal of Environmental Toxicology, vol. 2, pp. 92-99, 2008.

[22] Awokunmi E.E., Asaolu S.S. and Ipinmoroti K.O. Effects of leaching on heavy metals concentrations of soil in some dumpsites. African Journal of Environmental Science and Technology, vol. 4, n8, pp. 495-499, 2010. 